\title{
STUDY OF NATURAL ADDITIVES' INFLUENCE ON THE MICROBIOLOGICAL STATUS OF CEREALS
}

\author{
Svetlana Grigorova $^{1}$, Evgeni Petkov ${ }^{1}$, Natasha Gjorgovska ${ }^{2}$ \\ ${ }^{1}$ Institute of Animal Science, AAS, sp. Pochivka, 2232 Kostinbrod, Bulgaria \\ ${ }^{2}$ Institute of Animal Science, University "Ss. Cyril and Methodius", \\ Blvd. Ilinden 92a, 1000 Skopje, North Macedonia \\ svet.grigorova@mail.bg
}

\begin{abstract}
A b s t r a c t: The antioxidant, antibacterial and antifungal effects of the natural plant additives such as turmeric powder, dry extract of geranium (Geranium sanguineum) and oregano oil on the contents of bacteria and moulds as well as the changes of $\mathrm{pH}$ and peroxide values in maize, wheat, barley and triticale during storage were studied. These additives have in a different extent, an inhibitory influence on the bacteria and moulds in the cereals chosen for the study, which depends on their composition and micro-organisms' strain activity. Their influence is directed mainly to the representatives of Aspergillus and Penicillinum species, whereas they have almost no influence on those of the genus Fusarium. Oregano oil achieved the highest antibacterial and antifungal effect. Turmeric powder showed a pronounced antifungal effect in wheat, barley and triticale. Geranium's dry extract had a strong antibacterial effect, at the same time achieving only a weak antifungal effect. On $58^{\text {th }}$ day and $136^{\text {th }}$ day after the addition of these herbal additives, $\mathrm{pH}$ values were higher than those in untreated grains. The highest $\mathrm{pH}$ value was measured in the grains treated with oregano oil. All the $\mathrm{pH}$ values measured are within the normal range for maize and cereals, showing values between 5.41 and 6.44 . Peroxide values obtained in the whole period of the trial don't exceed $8 \mathrm{mEq} \mathrm{O} / \mathrm{kg}$. These values are lower in the treated cultures than in the untreated ones.
\end{abstract}

Key words: turmeric powder; Geranium sanguineum; oregano oil; cereals; mycological status

\section{СТУДИЈА ЗА ВЛИЈАНИЕТО НА ПРИРОДНИТЕ АДИТИВИ ВРЗ МИКРОБИОЛОШКИОТ СТАТУС НА ЖИТАРКИТЕ}

А п с т р а к т: Испитувани се антиоксидантните, антибактериските и антифунгалните ефекти на природни растителни адитиви (куркума во прав, сув екстракт од гераниум (Geranium sanguineum) и масло од оригано) врз содржината на бактерии и мувли, како и промените на вредностите на $\mathrm{pH}$ и на пероксидот кај пченката, пченицата, јачменот и тритикалето за време на складирање. Овие адитиви во различна мера имаат инхибиторно влијание врз бактериите и мувлите во житарките избрани за студијата во зависност од нивниот состав и активноста на микроорганизмите. Тие влијаат главно врз претставниците на видовите Aspergillus и Penicillinum, додека речиси и не влијаат на оние од родот Fusarium. Маслото од оригано го постигна највисокиот антибактериски и антифунгален ефект. Правот од куркума покажа изразит антифунгален ефект кај пченицата, јачменот и тритикалето. Сувиот екстракт на гераниум имаше силен антибактериски ефект, истовремено постигнувајќи само слаб антифунгален ефект. На 58-иот и 136-иот ден по додавањето на овие растителни адитиви, вредностите на $\mathrm{pH}$ беа повисоки од оние во нетретираните зрна. Највисоката $\mathrm{pH}$-вредност беше измерена во

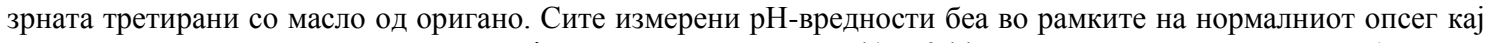
пченката и житните култури, покажувајќи вредности помеѓу 5,41 и 6,44. Пероксидните вредности добиени во целиот период на испитувањето не надминуваа $8 \mathrm{mEq} \mathrm{O} 2 / \mathrm{kg}$. Овие вредности се пониски кај третираните отколку кај нетретираните култури.

Клучни зборови: прав од куркума; Geranium sanguineum; масло од оригано; житарки; микробиолошки статус 


\section{INTRODUCTION}

Proper storage of cereals is a prerequisite for the production of good-quality compound feeds. Grain is a natural environment for the development of various micro-organisms - bacteria and mould fungi which, if the grain is not properly stored, proliferate rapidly causing changes in its chemical composition and nutritional value (Adams, 2008) as well as possible accumulation of mycotoxins (Tankov, 2000). The main species of mould fungi having an important role in the microbial decomposition of the raw materials, are those of the genera Aspergilus, Penicilium, Fusarium, Mucor, Cladosporium, Alternaria (Chang-Yen et al., 1992; Valcheva \& Grigorova, 2005). Treatment of grain for mould fungi growth's limitation and minimization mycotoxins' negative effects, can be made by chemical, physical and biological methods.

Physical methods are: heat treatment, cleansing, separation, technological treatments, $\gamma$ radiation and UV irradiation.

During chemical treatments all kinds of chemical compounds are used: bentonite, zeolite, organic acids (formic, propionic, lactic, fumaric, citric), inorganic acids (phosphoric), $\mathrm{H}_{2} \mathrm{SO}_{4}, \mathrm{H}_{2} \mathrm{O}_{2}, \mathrm{NaHCO}_{3}$, $\mathrm{NH}_{4} \mathrm{OH}$ or gaseous $\mathrm{NH}_{3}$, which have the capacity to destroy or deactivate the mycotoxins (Valcheva, 2005). However, the feed manufacturers more and more often avoid the use of certain chemicals, such as ammonia, which despite their strong antimycotic effect are potentially dangerous for the human health and pollute the environment.

The latest generation of examined and implemented in the practice methods (biological) for deactivation of the mycotoxins have been elaborated on the basis of various enzymes, live yeast cultures, micro-organisms of the digestive tract, glucomannans, and other (Lizarraga et al., 2013, Valcheva, 2005). Such product from a completely new generation is Mtox+ created on the basis of nanotechnologies and containing nanoclays, extracts of aquatic plants and Saccharomyces cerevisiae (www.agroyug.ru/htmledit/download/ 09.pdf).

Concerns about possible residuals of chemical fungicidal and bactericidal preparations in animal products like meat, milk and eggs have caused great caution in their use in feed for livestock and poultry (Rahimi et al., 2011). For this reason, the people engaged in the field of feed industry have united their efforts in the search for natural additives having antimicrobial action, as an alternative to the synthetic products. In this direction a subject of interest are herbs, spices and ethereal oils. They are natural feed and food additives, containing biologically active substances (BAS) with multiple action, also they are not toxic and enjoy public approval (Abadjieva \& Kistanova, 2011; Grigorova, 2014; Wenk, 2002). A lot of tests are described in the literature, where herbal essential oils with pronounced antibacterial and antifungal effects have been used. However, this approach needs further studies.

The objective of the current research is to examine the influence of natural additives turmeric powder, dry extract of Geranium sanguineum and oregano oil on the contents of mould fungi spores and bacteria, as well as on $\mathrm{pH}$ and the peroxide values in maize, wheat, barley and triticale during storage.

\section{MATERIALS AND METHODS}

In this study, the following natural additives have been used:

- Turmeric powder (origin - India). It contains $3.5 \%$ curcumin (the main biologically active substance, to which the antibacterial, antifungal and antioxidant action of turmeric is owed);

- Dry extract of geranium (Geranium sanguineum), a product of the company Vemo $99 \mathrm{Ltd}$, Sofia, Bulgaria. The extract contains the polyphenols catechin (22.5\%-27.5\%) and tannin (25\%), as well as $0.3 \%$ of antocyanides (water-soluble pigments), which are its BASs;

- Oregano oil, a product of the company Kandimin, Finland. It contains $80 \%$ carvacrol, the main active substance of this additive.

Representative mean samples were taken from each of the tested cereals (maize, wheat, barley, triticale) harvested in 2013 and kept in the grain store in the Institute of Animal Science - Kostinbrod, Bulgaria. Six replicates (300 g each) from each of the studied grain cultures were made for each of the examined naturel additives (turmeric powder, geranium and oregano oil) and for control group (without additives). All the samples were put in glass jars and homogenized well. Then in the experimental samples were added $2 \%$ turmeric powder, $1 \%$ geranium dry extract and $0.6 \%$ oregano oil. All the samples were kept at room temperature. The changes were checked for on the $58^{\text {th }}$ and $136^{\text {th }}$ day of the trial.

For determination of total viable count and aerobic spore forming bacteria, $10 \mathrm{~g}$ of samples were put in $90 \mathrm{ml}$ sterile physiological solution. Decimal 
dilutions were made also by using sterile physiological solution. Total viable counts were analyzed by using Plate count agar after incubation on $30^{\circ} \mathrm{C}$ for $48 \mathrm{~h}$. The determination of the number of aerobic spore-forming bacteria was made by pipetting $2 \times 10$ $\mathrm{ml}$ of basic food solution into sterile tubes. The tubes were then heat in hot water bath $\left(81^{\circ} \mathrm{C}\right)$. After that tubes with basic food solution were cooled and the further decimal dilutions were made. The Plate count agar was used for counting the spore-forming bacteria after incubation on $30^{\circ} \mathrm{C}$ for $48 \mathrm{~h}$.

For determination of moulds $10 \mathrm{~g}$ of samples were put in $90 \mathrm{ml}$ sterile physiological solution and the further decimal dilutions were performed. Czapek Dox agar was inoculated with the sample and incubated in a thermostat at the temperature of $25^{\circ} \mathrm{C}$, in a period of 5-7 days (Stankushev et al., 1971). The developing colonies were counted.

For detection of the moulds that may develop inside the examined grain samples the following procedure was performed: 100 seeds of subsequent seed samples were disinfected with concentrated solution of sodium hypochlorite and washed three times with sterile water. 25 of disinfected seeds were put into Petri dishes filed with Czapek Dox agar and incubated at the temperature of $25^{\circ} \mathrm{C}$, in a period of 5-7 days. The number of seeds grown with moulds is count and the results were presented in percents.

At the beginning of the trial the following parameters of all cereals samples were determined: pH values (using pH-meter Stirrer, Type OP-95); total lipid content (TLC) by the method of Bligh and Dyer (1959); peroxide values according to Bulgarian State Standard EN 3960/2001. These indicators were also determined on days $58^{\text {th }}$ and $136^{\text {th }}$ after the addition of $2 \%$ of turmeric powder, $1 \%$ of Geraniums dry extract and $0.6 \%$ of oregano oil.

The results obtained were statistically processed by Excel 2000, single factor, ANOVA program. The results are presented as means with their standard errors.

\section{RESULTS AND DISCUSSION}

In Table 1 are presented the changes in the number of bacteria and moulds, occurred in the tested samples containing maize, wheat, barley and triticale with the addition of turmeric powder, dry extract of Geranium sanguineum and oregano oil.

Table 1

Changes in number of bacteria and moulds in maize, wheat, barley and triticale grains before disinfection, number per $g(X \pm S E)$

\begin{tabular}{|c|c|c|c|c|}
\hline $\begin{array}{ll}\text { Items } & \text { Additives } \\
\end{array}$ & $\begin{array}{c}\text { Control } \\
\mathrm{n}=6\end{array}$ & $\begin{array}{c}\text { Turmeric } \\
n=6\end{array}$ & $\begin{array}{c}\text { Geranium } \\
n=6\end{array}$ & $\begin{array}{c}\text { Oregano oil } \\
n=6\end{array}$ \\
\hline \multicolumn{5}{|l|}{ Maize } \\
\hline Total bacterial count & $139500 \pm 219.09$ & $32500 \pm 196.07^{* * * *}$ & $14000 \pm 76.38^{* * *}$ & $21500 \pm 102.4^{* * *}$ \\
\hline Spore forming bacteria & $68500 \pm 60.09$ & $7500 \pm 48.30^{* * *}$ & $13500 \pm 65.83^{* * *}$ & $20500 \pm 65.83^{* * *}$ \\
\hline Moulds & $17000 \pm 53.23$ & $45500 \pm 48.16$ & $72000 \pm 285.19$ & $1500 \pm 100.82^{\text {**** }}$ \\
\hline \multicolumn{5}{|l|}{ Wheat } \\
\hline Total bacterial count & $40000 \pm 306.40$ & $55500 \pm 152.75$ & $20000 \pm 57.74^{* * *}$ & $2000 \pm 48.30^{* * *}$ \\
\hline Spore forming bacteria & $7500 \pm 88.50$ & $51500 \pm 100.06$ & $16500 \pm 53.87$ & $2000 \pm 48.30^{* * *}$ \\
\hline Moulds & $500 \pm 48.30$ & $500 \pm 38.73$ & $500 \pm 38.73$ & - \\
\hline \multicolumn{5}{|l|}{ Barley } \\
\hline Total bacterial count & $37000 \pm 246.31$ & $74500 \pm 263.31$ & $66500 \pm 264.57$ & $5000 \pm 123.15^{* * *}$ \\
\hline Spore forming bacteria & $8000 \pm 77.45$ & $35500 \pm 189.30$ & $17500 \pm 78.05$ & $3000 \pm 54.10^{* * * *}$ \\
\hline Moulds & $8000 \pm 87.97$ & $2500 \pm 99.16$ & $1500 \pm 64.54^{* * *}$ & $1500 \pm 60.52^{* * *}$ \\
\hline \multicolumn{5}{|l|}{ Triticale } \\
\hline Total bacterial count & $39000 \pm 278.80$ & $48000 \pm 356.83$ & $3500 \pm 188.57^{* * * *}$ & $2500 \pm 139.40^{* * * *}$ \\
\hline Spore forming bacteria & $3500 \pm 169.31$ & $3000 \pm 139.04$ & $1500 \pm 96.61^{* * *}$ & $500 \pm 43.60^{* * *}$ \\
\hline Moulds & $4500 \pm 146.06$ & $3000 \pm 152.75^{*}$ & $2000 \pm 140.20^{* *}$ & - \\
\hline
\end{tabular}

Significant in each row: ${ }^{*}=\mathrm{P}<0.05 ;{ }^{* *}=\mathrm{P}<0.01 ;{ }^{* * *}=\mathrm{P}<0.001$ 
Turmeric powder suppresses significantly $(\mathrm{P}<0.001)$ the development of the bacteria disposed in the maize (the total number of bacteria dropped four-fold - from 139.500 to 32.500 units/g). Geranium reduces the amount of bacteria in maize approximately 10 times $(\mathrm{P}<0.001)$, in wheat 2 times $(\mathrm{P}<0.001)$ and in triticale 11 times $(\mathrm{P}<0.001)$. Oregano oil significantly $(\mathrm{P}<0.001)$ reduces the number of both sporogenic and moulds in all the examined samples. The moulds in wheat and triticale grains were completely destroyed.

In Table 2 are presented the changes in the mould contents in the grain cultures treated with turmeric, Geranium sanguineum dry extract and oregano oil, after treatment with sodium hypochlorite.

In the experiment on antifungal effect of the turmeric in the maize was registered, while in the barley was registered a complete liquidation of the fungi of the genus Aspergillus and a huge reduction of those of the genus Penicillium (reduced from $40 \%$ to $1 \%$ ). In barley, the turmeric reduces (from $78 \%$ to $15 \%$ ) the quantity of moulds of the genus Aspergillus and of the genus Penicillium (from 56\% to $6 \%$ ). In triticale, the turmeric reduces (from $56 \%$ to $6 \%$ ) the quantity of mould fungi of the genus Aspergillus, while in a much lesser extent of those of the genus Penicillium (from 12\% to 6\%).

The dry extract of Geranium sanguineum has a weaker antifungal effect. Namely, in maize it caused a reduction of the quantity of moulds of the genus Penicillium from $72 \%$ to $36 \%$. In wheat, the quantity of moulds of the genus Aspergillus decreased from $20 \%$ to $9 \%$, and of those of the genus Penicillium decreased from $40 \%$ to $1 \%$. The geranium extract reduced the quantity of mould fungi of the genus Aspergillus from $80 \%$ to $44 \%$ in barley, and from $12 \%$ to $4 \%$ in wheat.

In our study, the oregano oil showed the strongest antibacterial and antifungal effect. As a consequence, in maize the moulds of the genus Aspergillus were completely eliminated, and those of the genus Penicillium were significantly reduced, from $72 \%$ to $3 \%$. In wheat, the members of the genera Aspergillus and Penicillium were completely eliminated. In barley, the amount of moulds decreased considerably for both Aspergillus and Penicillium species (from $78 \%$ to $9 \%$ for the former, and from $56 \%$ to $2 \%$ for the latter). In triticale, the amount of Aspergillus genera decreased from $80 \%$ to $2 \%$, and of Penicillium genera - from $12 \%$ to $4 \%$. Similar results were obtained by Ibrahim et al. (2012); Shimoni et al. (1993). According to Rasha et al. (1995), oregano oil has inhibiting action not only on the members of Aspergillus and Penicillium genera, but also of those of the genera Alternaria, Cladosporium, Helmintosporium, Mucor and Rhisopus. The natural additives examined in our study don't have any inhibitory action only on the members of the genus Fusarium.

Table 2

Changes in the content of moulds after treatment of maize, wheat, barley and triticale grains, $\%$

\begin{tabular}{|c|c|c|c|c|c|c|c|c|c|c|c|c|c|c|c|c|c|}
\hline \multirow{2}{*}{ Moulds } & & \multicolumn{4}{|c|}{ Maize } & \multicolumn{4}{|c|}{ Wheat } & \multicolumn{4}{|c|}{ Barley } & \multicolumn{4}{|c|}{ Triticale } \\
\hline & & $\mathrm{C}$ & $\mathrm{T}$ & GS & $\mathrm{O}$ & $\mathrm{C}$ & $\mathrm{T}$ & GS & $\mathrm{O}$ & $\mathrm{C}$ & $\mathrm{T}$ & GS & $\mathrm{O}$ & $\mathrm{C}$ & $\mathrm{T}$ & GS & $\mathrm{O}$ \\
\hline \multirow{2}{*}{ Fusarium } & - & 2 & 2 & 3 & 3 & 8 & 14 & 18 & 28 & 3 & 5 & 5 & 5 & 10 & 18 & 16 & 13 \\
\hline & $\bullet$ & 6 & 6 & 2 & 3 & 18 & 24 & 26 & 10 & - & 3 & 2 & 2 & 11 & 15 & 14 & 7 \\
\hline \multirow{2}{*}{ Aspergillus } & • & 8 & 100 & 117 & 37 & 22 & 38 & 41 & - & 73 & 19 & 42 & 13 & 87 & 18 & 53 & 3 \\
\hline & $\bullet$ & 8 & 8 & 75 & $4 \cdots$ & 20 & - & 9 & - & 78 & 15 & 50 & 9 & 80 & 10 & 44 & 2 \\
\hline \multirow{2}{*}{ Penicillium } & • & 33 & 17 & 20 & 2 & 45 & 28 & 6 & - & 50 & 5 & 25 & 4 & 15 & 5 & 2 & 1 \\
\hline &.$\bullet$ & 72 & 75 & 36 & 3 & 40 & 1 & 1 & - & 56 & 6 & 52 & 2 & 12 & 6 & 3 & 4 \\
\hline \multirow{2}{*}{ Mucor } & • & 51 & 90 & 75 & - & 36 & 43 & 25 & - & 22 & 13 & 28 & 15 & 18 & 28 & 30 & 3 \\
\hline & •. & 52 & 44 & 56 & 6 & 40 & 35 & 17 & 10 & 30 & - & 16 & 11 & 16 & 5 & 20 & 12 \\
\hline \multirow{2}{*}{ Rhizopulus } & • & - & 70 & 70 & - & - & 10 & 5 & - & & & & & & & & \\
\hline & $\bullet$ & 3 & 27 & 35 & - & 5 & - & - & - & & & & & & & & \\
\hline \multirow{2}{*}{ Alternaria } & • & & & & & 7 & 19 & 18 & 5 & - & 3 & 5 & - & - & 10 & 6 & - \\
\hline & $\bullet$ & & & & & 11 & 15 & 22 & - & 2 & 2 & 7 & - & - & 11 & 10 & - \\
\hline \multirow{2}{*}{ Cladosporium } & • & & & & & 19 & 13 & 21 & 5 & 5 & 7 & 9 & - & 47 & 27 & 13 & 6 \\
\hline & $\bullet$ & & & & & 21 & 9 & 26 & - & 3 & 2 & 9 & - & 36 & 13 & 11 & 2 \\
\hline
\end{tabular}

$\mathrm{C}=$ Control, $\mathrm{T}=$ Turmeric, $\mathrm{GS}=$ Geranium sanguineum, $\mathrm{O}=$ Oregano oil;

$\bullet=$ registered on day $58, \bullet=$ registered on day $136, \cdots=$ heavily suppressed, without micelle 
The results obtained in our study allow us to draw a conclusion that the natural additives' antibacterial and antifungal action depends in the first place on their composition, as well as on the species of the cereals they are implemented in and the strain specifics of the particular micro-organism they act on.

Simultaneously with the microbiological examinations, the available moisture in both the treated and untreated cultures was also followed up. Namely, the available moisture decreased insignificantly (P > 0.05) in all the cultures (from $14.5 \%$ to $11 \%$ in maize, from $12.65 \%$ to $11.64 \%$ in wheat, from $11.63 \%$ to $10.64 \%$ in barley and from $13.02 \%$ to $11.63 \%$ in triticale), therefore this decrease was not a cause for the microbiological changes that occurred.
In Table 3 are given total lipid contents, peroxide values and $\mathrm{pH}$ values in the examined cereals, before and after their treatment with the tested natural additives. Concerning TLC there are not significant differences $(\mathrm{P}>0.05)$ between control and treated cereals. The peroxide value is an indicator for the presence of peroxides which are a product of the initial oxidizing processes in the fats. If the peroxide value is above $20 \mathrm{mEq} \mathrm{O} / \mathrm{kg}$, the fats are oxidized, while if it is $10 \mathrm{mEq} \mathrm{O} / \mathrm{kg}$ or lower there are no substantial changes in the organoleptic properties of the fats. Since the grain cultures used in our study are not rich in fats, peroxide values obtained in the course of the experiment didn't exceed $8 \mathrm{mEq}$ $\mathrm{O}_{2} / \mathrm{kg}$, being lower than in the untreated grain cultures.

\section{Table 3}

Total lipid content (TLC), peroxide values $(P V)$ and $P$ values of maize, wheat, barley, triticale samples at the beginning of the trial without antioxidant ingredients; at $58^{\text {th }}$ day and $136^{\text {th }}$ day after addition of the tested additives $(X \pm S E)(n=6)$

\begin{tabular}{|c|c|c|c|c|c|c|c|c|c|}
\hline \multirow{2}{*}{$\begin{array}{l}\text { Periods items } \\
\text { Grain culture } \\
+,- \text { additive }\end{array}$} & \multicolumn{3}{|c|}{ At the beginning of the trial } & \multicolumn{3}{|c|}{ At $58^{\text {th }}$ day } & \multicolumn{3}{|c|}{ At $136^{\text {th }}$ day } \\
\hline & $\begin{array}{c}\text { TLC } \\
\mathrm{g} / 100 \mathrm{~g}\end{array}$ & $\begin{array}{c}\mathrm{PV} \\
\mathrm{mEq} \mathrm{O}_{2 / \mathrm{kg}}\end{array}$ & $\mathrm{pH}$ & $\begin{array}{c}\text { TLC } \\
\mathrm{g} / 100 \mathrm{~g} .\end{array}$ & $\begin{array}{c}\mathrm{PV} \\
\mathrm{mEq} \mathrm{O}_{2 /} \mathrm{kg}\end{array}$ & $\mathrm{pH}$ & $\begin{array}{c}\text { TLC } \\
\mathrm{g} / 100 \mathrm{~g}\end{array}$ & $\begin{array}{c}\mathrm{PV} \\
\mathrm{mEq} \mathrm{O}_{2 /} \mathrm{kg}\end{array}$ & $\mathrm{pH}$ \\
\hline Maize & $3.27 \pm 0.009$ & $8.91 \pm 0.013$ & $5.65 \pm 0.027$ & $3.25 \pm 0.01$ & $8.57 \pm 0.014^{\mathrm{ABC}}$ & $5.72 \pm 0.06^{\mathrm{abc}}$ & $3.26 \pm 0.009$ & $8.59 \pm 0.013^{\mathrm{A}_{2} \mathrm{~B}_{2} \mathrm{C}_{3}}$ & $6.06 \pm 0.08$ \\
\hline Maize + GS & & & & $3.24 \pm 0.012$ & $1.32 \pm 0.008^{\mathrm{A}}$ & $5.94 \pm 0.09^{\mathrm{a}}$ & $3.25 \pm 0.009$ & $2.30 \pm 0.04^{\mathrm{A} 2}$ & $5.98 \pm 0.08$ \\
\hline Maize + turmeric & & & & $3.26 \pm 0.01$ & $1.55 \pm 0.01^{\mathrm{B}}$ & $6.05 \pm 0.1^{\mathrm{b}}$ & $3.26 \pm 0.013$ & $2.35 \pm 0.06^{\mathrm{B} 2}$ & $6.25 \pm 0.12$ \\
\hline Maize + oregano oil & & & & & $1.50 \pm 0.009^{\mathrm{C}}$ & $6.17 \pm 0.09^{c}$ & $3.53 \pm 0.011$ & $2.05 \pm 0.05^{\mathrm{C} 3}$ & $6.10 \pm 0.06$ \\
\hline Wheat & $0.89 \pm 0.012$ & $6.56 \pm 0.07$ & $5.62 \pm 0.014$ & $0.89 \pm 0.013$ & $6.56 \pm 0.07^{\mathrm{A} 1 \mathrm{~B} 1 \mathrm{C} 1}$ & $5.62 \pm 0.09^{\mathrm{ef}}$ & $0.90 \pm 0.011$ & $2.17 \pm 0.10^{\mathrm{A} 3}$ & $6.15 \pm 0.07^{\mathrm{b} 1}$ \\
\hline Wheat + GS & & & & $0.90 . \pm 0.012$ & $2.42 \pm 0.04^{\mathrm{A} 1}$ & $5.98 \pm 0.12$ & $0.91 \pm 0.012$ & $1.52 \pm 0.06^{\mathrm{A} 3}$ & $6.19 \pm .04$ \\
\hline Wheat + turmeric & & & & $0.91 \pm 0.013$ & $4.01 \pm 0.1^{\mathrm{B} 1}$ & $6.23 \pm 0.07^{\mathrm{e}}$ & $0.93 \pm 0.014$ & $1.98 \pm 0.08$ & $6.44 \pm 0.07^{\mathrm{b} 1}$ \\
\hline Wheat + oregano oil & & & & & $2.60 \pm 0.11^{\mathrm{C} 1}$ & $6.25 \pm 0.11^{\mathrm{f}}$ & $1.45 \pm 0.013$ & $2.12 \pm 0.07$ & $6.16 \pm 0.06$ \\
\hline Barley & $1.18 \pm 0.01$ & $3.21 \pm 0.14$ & $5.85 \pm 0.022$ & $1.18 \pm 0.014$ & $3.21 \pm 0.13$ & $5.85 \pm 0.09$ & $1.17 \pm 0.011$ & $2.56 \pm 0.10^{\mathrm{e} 2}$ & $6.00 \pm 0.07$ \\
\hline Barley + GS & & & & $1.19 \pm 0.012$ & $4.10 \pm 0.23$ & $5.63 \pm 0.09$ & $1.19 \pm 0.011$ & $2.83 \pm 0.07$ & $5.84 \pm 0.08$ \\
\hline Barley + turmeric & & & & $1.20 \pm 0.011$ & $3.78 \pm 0.23$ & $5.73 \pm 0.08$ & $1.20 \pm 0.012$ & $3.10 \pm 0.10^{\mathrm{e} 2}$ & $6.07 \pm 0.07$ \\
\hline Barley + oregano oil & & & & & $2.90 \pm 0.18$ & $5.66 \pm 0.08$ & $1.57 \pm$ & $2.15 \pm 0.08$ & $5.93 \pm 0.08$ \\
\hline Triticale & $1.15 \pm 0.012$ & $3.98 \pm 0.21$ & $5.86 \pm 0.015$ & $1.15 \pm 0.013$ & $3.98 \pm 0.22$ & $5.86 \pm 0.10^{\mathrm{elC} 2}$ & $1.16 \pm 0.012$ & $2.72 \pm 0.08^{\mathrm{A} 4 \mathrm{~B} 3}$ & $6.30 \pm 0.06^{\mathrm{f} 1}$ \\
\hline Triticale + GS & & & & $1.16 \pm 0.013$ & $4.28 \pm 0.16$ & $6.19 \pm 0.10$ & $1.16 \pm 0.012$ & $2.07 \pm 0.10^{\mathrm{A} 4}$ & $6.25 \pm 0.07$ \\
\hline Triticale + turmeric & & & & $1.16 \pm 0.011$ & $4.10 \pm 0.18$ & $6.30 \pm 0.10^{\mathrm{e} 1}$ & $1.16 \pm 0.013$ & $1.87 \pm 0.08^{\mathrm{B} 3}$ & $6.40 \pm 0.08$ \\
\hline Triticale + oregano oil & & & & & $3.70 \pm 0.19$ & $6.37 \pm 0.09^{\mathrm{C} 2}$ & $1.16 \pm 0.012$ & $3.00 \pm 0.07$ & $6.00 \pm 0.05^{\mathrm{f} 1}$ \\
\hline
\end{tabular}

Significant: a, b, $\mathrm{b}_{1 ;} \mathrm{c}-\mathrm{P}<0.05 ; \mathrm{e}, \mathrm{e}_{1-2}, \mathrm{f}, \mathrm{f}_{1}-\mathrm{P}<0.01 ; \mathrm{A}, \mathrm{A}_{1-4}, \mathrm{~B}, \mathrm{~B}_{1}, \mathrm{C}, \mathrm{C}_{1-2}-\mathrm{P}<0.001$ 
The initial $\mathrm{pH}$ values ranged between 5.44 in maize and 5.86 in triticale. On the $58^{\text {th }}$ day of the experiment, the $\mathrm{pH}$ had higher values in all the treated cultures than in the untreated cultures, the highest $\mathrm{pH}$ value being that in the cultures treated with oregano oil. The situation was same on $136^{\text {th }}$ day. All the $\mathrm{pH}$ values measured in the experiment are within the normal for grain cultures, ranging between 5.41 and 6.44 .

\section{CONCLUSIONS}

- The natural additives turmeric powder, dry extract of Geranium sanguineum and oregano oil, examined in our experiment, exhibit, in a various degree, an inhibiting action on the bacteria and moulds in the grain cultures used in our study. Their action is directed mainly to the members of the genera Aspergillus and Penicillium. They have no influence on the moulds from the genus Fusarium.

- Turmeric powder suppresses significantly ( $\mathrm{P}<$ 0.001) the development of the total number of bacteria in maize (their amount dropped fourfold - from 139.500 to 32.000 units/g). Geranium reduces the amount of bacteria in maize approximately 10 times $(\mathrm{P}<0.001)$, in wheat 2 times $(\mathrm{P}<0.001)$ and in triticale 11 times $(\mathrm{P}<$ $0.001)$. Oregano oil significantly $(P<0.001)$ reduces the amount of sporogenic bacteria.

- The highest antibacterial and antifungal effect is that of the oregano oil, used in our study in the concentration of $0.5 \mu \mathrm{g} / \mathrm{ml}$. The turmeric powder showed a well pronounced antifungal effect in wheat, barley and triticale.

- The dry extract of Geranium sanguineum has a strong antibacterial and a weak antifungal effect.

- On the $58^{\text {th }}$ and $136^{\text {th }}$ day after the addition of the herbal additives, the $\mathrm{pH}$ values were higher than those in the untreated cultures, the highest $\mathrm{pH}$ value being the one measured in the grain cultures treated with oregano oil. All the $\mathrm{pH}$ values we have registered in the experiment are within the normal for maize and cereals, ranging from 5.41 to 6.44 .

- The peroxide values we have obtained in the experiment don't exceed $8 \mathrm{mEq} \mathrm{O}_{2} / \mathrm{kg}$. These values are lower in the treated cultures than in the untreated ones.

Acknowledgment: We would like to thank Assoc. prof. Ph.D Antoaneta Valcheva (Institute of Animal Science -
Kostinbrod) for determination microbiological status of cereals, and Mr Hristo Zlatev (Vemo Ltd, Sofia, Bulgaria) for providing the Geranium sanguineum extract that was used in this study.

\section{REFERENCES}

Abadjieva, D., and Kistanova, E.: Opportunities to stimulate reproductive function in female Animals, Niva Povolja. Zootech., Vol. 4, pp. 71-75 (2011).

Adams, C.: Nutricines, Food Components in Health and Nutrition, Nottingham University Press, 2008.

Bligh, E. C., Dyer, W. J.: A rapid method of total lipid extraction and purification. Canad. J. Biochem. Physiol., 37, 911-917 (1959).

Chang-Yen, L., Bidasee, K., Rampersad, G.: Mycoflora and mycotoxin-produsing potential of fungi from poultry feed and feed ingredients in Trinidad, J. Sci. Food Agric., Vol. 60, pp. 283-286 (1992)

Grigorova, S.: Sources and importance of natural antioxidants in animal nutrition, J. Anim. Sci.(BG), Vol. 51, pp. 46-52, (2014).

Ibrahim, L., Karaky, M., Ajoub, P., Naval, E. A., Ibrahim, S. Chemical composition and antimicrobial activities of essential oil and its componends from Lebanese Origanum syriacum L., J. Essent. Oil Res., Vol. 24, pp. 339-345 (2012).

Lakis, Z., Mihele, D., Nicorescu, I., Vulturescu, V., Udeanu, D.: The antimicrobial activity of Thymus vulgaris and Origanum Syriacum essential oils on Staphylococcus aureus, streptococcus pneumone and Candida albicans, Farmacia, Vol. 60, pp. 857-862 (2012).

Lizarraga-Paulin, E. G., Lara-Sagahon, A. V., MorenoMartinez, E., Torres-Pacheco, I., Miranda-Castro, S. P.: Novel methods for preventing and controllingf aflatoxins in food: A wordwide daily challenge, Intech Open Access Publisher, 2013.

Rasha, K. D., Dagher, S. M., Sattout, E. J.: Antifungal activity of the Essential oil of Origanum syriacum L., J. Food Prot., Vol. 58, pp. 1147-1149 (1995).

Shimoni, M., Putievsky, E., Ravid, U., Reuveni, R.: Antifungal activity of volatile fractions of essential oils from four aromatic wild plants in Israel. J. Chem. Ecol., Vol. 19, pp. 1129-11233 (1993).

Stankushev, H. and Spesivtzeva. N.: Mycoses and Mycotoxicosis in Farm Animals, Zemizdat, Sofia, pp. 282-292, 1971.

Tankov, D. A.: Study on mycoflora and the spread of zearalenone and deoxinavalenol in wheat and corn for feed production, Dissertation, Sofia, Bulgaria, 2000.

Valcheva, A.: Study of mycological and mycotoxicological status of maize and wheat in feeding pigs and birds, Disseritation, Sofia, Bulgaria, 2005, pp. 137.

Valcheva, A., Grigorova, S.: The study on the effect of feeding of chicken broilers with combined forages containing a high share of wheat contaminated with fungi from the genus Fusarium, J. Anim. Sci. (BG), Vol. 42, pp. 14-18 (2005).

Wenk, C.: Herbs and botanicals as feed-additives in monogatric animals. In: Proceedings of International Symposium on Advances in Animal Nutrition, New Delhi, 2002, pp. 282289.

www.agroyug.ru/htmledit/download/09.pdf: Application of M Tox in pig breeding (2007). 